\title{
Opioid-Induced Hyperalgesia (OIH)
}

\author{
Plínio da Cunha Leal ${ }^{1}$, Jefferson Clivatti ${ }^{2}$, João Batista Santos Garcia, TSA ${ }^{3}$, Rioko Kimiko Sakata, TSA ${ }^{4}$
}

Summary: Leal PC, Clivatti J, Garcia JBS, Sakata RK - Opioid-Induced Hyperalgesia (OIH).

Background and objectives: Opioids are commonly used for pain control; however, they can cause hyperalgesia. The reason why this can happen is not known. The objective of this review was to describe the mechanisms, factors implicated, and drug modulation.

Contents: The factors implicated in the development of opioid-induced hyperalgesia $(\mathrm{OIH})$, such as duration of use, dose, and type of opioids are described. Mechanisms involved include the glutamatergic system and N-methyl-D-aspartate receptors (NMDA), spinal cyclooxygenase (COX) activation, excitatory amino acids, dynorphin, cytokines and chemokines; prostaglandins, and descending facilitation. Modulation of hyperalgesia could be done through: NMDA receptor antagonists, alpha2-adrenergic agonists, and COX inhibitors.

Conclusions: This is a very complex subject, which involves a series of pathophysiological mechanisms that could contribute for OIH and patient discomfort, bringing disastrous consequences.

Keywords: ANALGESICS, Opioids; COMPLICATIONS: hyperalgesia.

\section{INTRODUCTION}

Opioids are fundamental drugs in the treatment of pain ${ }^{1,2}$. Although they work as analgesics, evidence that opioids cause hyperalgesia does exist. Thus, paradoxically, the drug used to relieve pain makes the patient more sensitive to it ${ }^{~}$.

Therefore, initially they have analgesic and anti-hyperalgesic effects, but subsequently they can cause hyperalgesia ${ }^{1}$.

\section{OPIOID-INDUCED HYPERALGESIA (OIH)}

Opioid-induced hyperalgesia is the increased sensitivity to pain caused by exposure to opioids ${ }^{2}$. This phenomenon has a negative effect in pain treatment ${ }^{3}$.

Reports in the literature on the incidence of OlH are lacking; however, since it can affect individuals on opioids, we should be aware of it. The use of opioids is the required condition for the development of $\mathrm{OIH}$, both acute and chronic ${ }^{1-3}$. Administration of large doses of opioids for a prolonged period

\footnotetext{
Department of Anesthesiology, Pain, and Intensive Care Medicine of the Escola Paulista de Medicina of Universidade Federal de São Paulo (EPM/UNIFESP), SP.

1. R3 of CET/SBA Department of Anesthesiology, Pain, and Intensive Care Medicine of EPM/UNIFESP

2. Preceptor of Anesthesiology Residency Program of the Anesthesiology Department of EPM/UNIFESP

3. Anesthesiologist, Professor of Universidade Federal do Maranhão

4. Anesthesiologist, Coordinator of the Department of Pain and Intensive Care of EPM/ UNIFESP

Submitted on April 27, 2009.

Approved on June 4, 2010

Correspondence to:

Dra. Rioko Kimiko Sakata

Rua Três de Maio 61-51

V. Clementino

04044-020 - São Paulo, SP

E-mail: riokoks.dcir@epm.br
}

seems to be associated with a higher incidence of $\mathrm{OlH}{ }^{1,2,4}$. Opioid-induced hyperalgesia can also be seen when those drugs are administered for a short period ${ }^{3}$.

Opioid-induced hyperalgesia affects animals and humans who receive opioids and drug-addicts on methadone maintenance ${ }^{1,2,5-7}$. In opioid-dependent individuals, a heightened sensitivity to pain is observed, and its interruption causes hyperalgesia. Sensitivity in areas of trauma is observed ${ }^{1}$, but the type and location of this pain can be different from the original pain ${ }^{2,3,7,8}$. Opioid-induced hyperalgesia can develop differently for different types of pain ${ }^{1}$. In animals, hyperalgia, which varies according to the different stimuli (mechanical, thermal) is also observed after discontinuation of the opioid ${ }^{1}$. Opioid-dependent patients show sensitivity to cold, but not to electrical and mechanical stimuli ${ }^{1}$. Increased sensitivity to cold and heat without affecting pressure sensitivity can be observed ${ }^{1}$. A difference in chronic oncologic pain and nononcologic pain was not observed 4 .

After acute administration of opioid the anti-nociceptive effect is seen during 1 to 5 hours followed by a reduction of pain threshold for several hours (up to 10 days) ${ }^{2,4,8,10}$. The use of long-acting opioids after surgeries can mask hyperalgesia ${ }^{4}$. With chronic use, an anti-nociceptive effect is seen on the first day followed by the loss of the effect or even progressive hyperalgia ${ }^{1}$.

Evaluation of hyperalgesia can be done through the threshold for mechanical stimulus (per-incisional, in the palmar region of the carpus, or in the interior face of the forearm) or with the coldtolerance test 8,9 .

Animals recovering from $\mathrm{OIH}$ remain sensitized to the effects of hyperalgesia of opioids with greater vulnerability to pain ${ }^{1}$. This phenomenon is reversible to some extent, but it requires a long period of abstinence ${ }^{3}$.

Therefore, any chronic or acute use of opioids can cause hyperalgesia. 


\section{DISCUSSION BETWEEN TOLERANCE AND HYPERALGESIA}

Hyperalgesia is associated with central sensitization with reduction in pain threshold, expansion of the receptive field (stimulation of a neuron in the posterior horn of the spinal cord activates a greater peripheral area), and increase in the answer to the nociceptive stimulus. In $\mathrm{OIH}$, the dose/effect curve is deviated downward, i.e., the analgesic effect decreases along time with a specific dose of the opioid, without improvement with an increase in the dose - on the contrary, it can increase the pain ${ }^{1,2}$. The pain is more severe than the original or initial pain, is not well defined in terms of quality and location, and it is associated with a reduction in the threshold and tolerability ${ }^{5}$.

The phenomenon in which exposure to opioids leads to a reduction on its effect, requiring larger doses to maintain it, is called tolerance, i.e., the tolerant organism is less susceptible to the pharmacologic effect of a drug ${ }^{11}$. It reflects the reduction in the sensitivity to opioids, which is due to desensitization of the anti-nociceptive pathway ${ }^{3}$. In desensitization of the anti-nociceptive pathway, G-protein receptors are incapable of reducing intracellular cyclic AMP and, consequently, the inward movement of sodium and calcium. A reduction in membrane receptors by internalization is another reason for tolerance ${ }^{3}$. A shift of the dose/effect curve to the right is seen in tolerance ${ }^{1,2}$. It is characterized by a reduction of the analgesic potency and it improves with an increase in the dose of the medication or changing of the opioid ${ }^{1}$. Pharmacologically, they are distinct phenomena ${ }^{2}$. They can involve opposite cellular mechanisms, with desensitization (tolerance) and sensitization $(\mathrm{OIH})^{6}$. In clinical practice it is difficult, and even impossible to distinguish the two phenomena. Hyperalgesia can mask anti-nociception producing the impression of tolerance ${ }^{7}$. Both conditions probably coexist and evidence that tolerance and hyperalgesia share several cellular mechanisms and some neurotransmitters and receptors systems, including dynorphin, protein kinase-C, NMDA receptors, nitric oxide synthase, heme oxigenase, and others exists ${ }^{1}$. Other cellular mechanisms differ in tolerance and hyperalgesia ${ }^{3}$. However, the mechanisms might not contribute in the same proportion for the loss of the analgesic effect. The expression of both phenomena may vary, depending on the treatment protocol and type of study ${ }^{1}$.

\section{MECHANISMS OF OIH}

Most likely, multiple factors and mechanisms contribute for $\mathrm{IOH}$, such as: anti-analgesic system, changes in NMDA receptors and intracellular second messengers, spinal COX activation, release of excitatory amino acids, reduction if inhibitory neurotransmitters, increased in phosphorylation, and descending facilitation 1,2,6,7,10,11. Neuroplastic changes can be seen in the central and peripheral nervous system, with sensitization of pro-nociceptive pathways ${ }^{2}$. Cellular changes are seen in several anatomical sites, such as afferent neurons and spinal cord, glia, encephalic nuclei, and descending modulation pathways ${ }^{2,3}$. Changes can be seen in receptors and channels, as well as peripheral and central sensitization $9,11-13$.

\section{Activation of NMDA receptors}

Activation of NMDA receptors by glutamate is implicated in the mechanism of $\mathrm{OIH}^{1,3,6}$. The increase in the release of glutamate in the dorsal horn of the spinal cord and the sustained increase in the response of NMDA receptors through protein kinase-Cmediated manganese removal, seem to be the main mechanisms implicated in OIH ${ }^{5,10}$. NMDA receptors can be activated by opioids, which behave as excitatory neurotransmitters, causing the inward flow of calcium and central sensitization. The inward flow of calcium increases the activity of protein kinase-C, phosphorylation, and inactivation of opioid receptors, besides causing an increase of nitric oxide synthase ${ }^{10}$. The inactivation of protein kinase- $C$ causes phosphorylation of NMDA receptors, with the removal of magnesium from the channels and an increase in the inward flow of calcium.

\section{Increase of anti-opioid peptides}

Excitatory amino acids are implicated in the process of hyperalgesia ${ }^{1}$. Opioid-induced hyperalgesia has been associated to the increase in cholecystokinin, a peptide related to the calcitonin gene (CGRP), substance-P, and nociceptin in the rostral ventromedial medulla due to an increase in the expression of excitatory opioid receptors in detriment of inhibitory opioid receptors $6,14,15$.

\section{Descending facilitation}

Another mechanism involves descending facilitation pathways, which are mediated by opioids in on-cells located in the rostral ventromedial medulla ${ }^{16}$. Exposure to morphine causes neuroplastic changes in the rostral ventromedial medulla, descending facilitation through on-cells, with increase in dynorphin, and release of neurotransmitters in primary afferent fibers ${ }^{2,7}$.

\section{Dynorphin function}

Administration of opioids provokes an increase in dynorphin, which might be one of the responsible factors for OIH ${ }^{6,7}$. Spinal dynorphin is pro-nociceptive and there is evidence that it causes the release of excitatory neurotransmitters from primary afferent neurons, suggesting positive retro-feeding that amplifies sensorial afference ${ }^{7}$.

\section{Other mechanisms}

Prostaglandins might be important. Cytokines and chemokines might also be relevant for the development of $\mathrm{OIH}{ }^{1,2}$. 
Opioids facilitate the release of cytokines 1,2,17. An increase in $\mathrm{C}$-fos protein is seen in sensorial neurons in the spinal cord ${ }^{1,2}$. The nitric oxide synthase system and heme oxigenase might be involved in $\mathrm{OlH}$. The reduction of inhibitory glycinergic control is a possible mechanism ${ }^{1}$.

\section{HYPERALGESIA-RELATED FACTORS}

\section{Dose}

Exposure to large doses of opioids seems to be associated with $\mathrm{OIH} 1,4,7,9,10,18$. Studies have demonstrated that large doses of intraoperative remifentanil cause an increase in postoperative pain $2,4,5,8,9$. However, OlH was observed after interruption of an infusion of $3.1 \mathrm{ng} \cdot \mathrm{mL}^{-1}$ of remifentanil ${ }^{19}$. On the other hand, a study failed to demonstrate an increase in postoperative opioid consumption after the use of large doses of remifentanil 20.

Large or repetitive doses of intraoperative fentanyl also have induced an increase in postoperative pain 5,21 . However, OlH has also been observed with small doses of fentanyl during maintenance of a dependent individual ${ }^{2}$. The case of a patient using a fentanyl adhesive $\left(75 \mu \mathrm{g}\right.$.day $\left.{ }^{-1}\right)$ for chronic pain, who underwent general anesthesia with remifentanil and developed more severe pain postoperatively has also been reported ${ }^{22}$.

Hyperalgia was observed with oral oxycodone $(2,400$ mg.day $\left.{ }^{-1}\right)$, oral methadone (675 mg.day $\left.{ }^{-1}\right)$, and intravenous methadone $\left(30 \mathrm{mg}^{\mathrm{h}} \mathrm{h}^{-1}\right)^{23}$. Methadone $62 \mathrm{mg}^{2} \cdot \mathrm{day}^{-1}$ also caused hyperalgesia ${ }^{24}$.

\section{Type of opioid}

The authors of a study have reported that some conditions of the molecule, such as the structure of fenantrene, hydrogen in position 14, ether binding, one or no methyl group bound to nitrogen, and free $\mathrm{OH}$ in position 3 free or conjugated with glucuronide/sulfate are necessary for the development of $\mathrm{OlH}^{25}$. Thus, the molecular formula seems to be important in inducing $\mathrm{OIH}^{1}$. However, $\mathrm{OlH}$ developed even with piperidine derivatives like fentanyl ${ }^{1}$.

It seems that the action on $\mu$ receptors is relevant 1,2 ; however, it is possible that opioids with action on kappa receptors also can cause $\mathrm{OIH}^{1}$.

Another factor implicated seems to be the short duration of action of opioids, such as remifentanil ${ }^{5,9,21,26-30}$. On the other hand, in most studies on OlH involving chronic pain, morphine seems to be implicated raising the possibility that the metabolite morphine-3-glucuronide has a contribution ${ }^{2}$. Opioid-induced hyperalgesia has been observed in four weeks after exposure to moderate doses of morphine $\left(75 \text { mg.day }^{-1}\right)^{2}$.

Some opioids can be associated to a higher possibility of inducing $\mathrm{OlH}$. Besides, crossed sensitization with other opioids has been observed 6 .

\section{Duration of use and of hyperalgesia}

Opioid-induced hyperalgesia is more evident with prolonged use ${ }^{3,6,14}$. Chronic use of oral morphine for 4 weeks was associated with hyperalgesia ${ }^{2}$. However, a study demonstrated the presence of hyperalgia in patients who used only opioids intraoperatively 8 .

Studies in rats treated with large doses of intravenous morphine and fentanyl during one hour demonstrated that hyperalgesia had a duration of 2 to 3 hours ${ }^{3,6,18}$. However, hyperalgesia can last anywhere from 2 to 10 days ${ }^{10,31}$.

\section{Type and route of administration}

Several routes of administration are implicated in $\mathrm{OlH}$ 21,32,33. Pain can be seen during continuous infusion of opioids, going against the hypothesis that the sensorial change is associated with suspension of the opioid $2,5,7$.

\section{MODULATION OF OIH}

Several drugs have been used in an attempt to reduce the development of $\mathrm{OIH}^{1,2,15,34}$.

NMDA receptor blockers can prevent or reduce the development of $\mathrm{OlH}^{5}$. Evidence that low dose ketamine can modulate $\mathrm{OlH}$ exists ${ }^{2,9,10,28,35,36}$.

Ketamine, $0.15 \mathrm{mg}^{\mathrm{kg}}{ }^{-1}$, followed by the intraoperative infusion of $5 \mu \mathrm{g} \cdot \mathrm{kg} \cdot \mathrm{min}^{-1}$ reduced morphine consumption and pain scores, delaying the time for the first complementation ${ }^{36}$. In another study low dose ketamine $\left(0.5 \mathrm{mg}^{\mathrm{kg}}{ }^{-1}\right)$ for induction, and infusion of $5 \mu \mathrm{g} \cdot \mathrm{kg}^{-1} \cdot \mathrm{min}^{-1}$, prevented remifentanil-induced hyperalgesia ${ }^{9}$. However, in rather another study ketamine did not prevent the development of $\mathrm{OIH}^{37}$.

Methadone is a weak NMDA receptor antagonist and, when hyperalgesia caused by another opioid is suspected, it can be switched to methadone ${ }^{2}$. However, methadone can be associated with states of heightened pain ${ }^{2}$. Therefore, opioids should be changed to methadone keeping in mind that it can also activate pro-nociceptive pathways ${ }^{23}$. Dextrorphan is an antitussive with non-competitive NMDA receptor antagonist and controversial effects on $\mathrm{OIH}^{2}$. Memantine is a MNDA receptor antagonist used in patients with Alzheimer's that needs more evaluation ${ }^{38}$.

It has been proposed that propofol can be used as an antihyperalgesic due to its action in gamma-aminobutyric acid receptors on the supraspinal level ${ }^{2,30}$. In a study, $1.5 \mu \mathrm{g} \cdot \mathrm{mL}^{-1}$ of propofol delayed the hyperalgesic effect of remifentanil; however, an increase in hyperalgesia was observed after the discontinuation of the drug and one should be aware to the possible affect of activating pro-nociceptive pathways ${ }^{34}$.

COX-2 inhibitors seem to have a relevant role in inhibiting hyperalgesia by stimulating the reuptake of glutamate in the dorsal horn of the spinal cord besides blocking NMDA receptors ${ }^{2}$. In volunteers, the prior administration of parecoxib, $40 \mathrm{mg}$ IV, reduced remifentanil-induced hyperalgesia 
$\left(0.1 \mu \mathrm{g} \cdot \mathrm{kg}^{-1} \cdot \mathrm{min}^{-1}\right)$. However, when parecoxib was administered in parallel with remifentanil this effect was not observed ${ }^{39}$.

In volunteers, clonidine, $2 \mu \mathrm{g} \cdot \mathrm{kg}^{-1}$, reduced pain scores caused by remifentanil $\left(0.1 \mu \mathrm{g} \cdot \mathrm{kg}^{-1} \cdot \mathrm{min}^{-1}\right){ }^{40}$.

\section{CLINICAL IMPLICATIONS}

It is often difficult to determine whether $\mathrm{OIH}$ developed after the administration of opioids. The reduction in analgesic efficacy could be due to tolerance, $\mathrm{OlH}$, or both 6 .

One should consider the presence of opioid-induced hyperalgesia when repetitive increases in dose fails to promote analgesia, causes exacerbation of the pain, causes an unexplainable decrease in the effects of the opioid, or diffuse allodynia not associated to the previous pain is observed, and other causes, such as progression of the disease or acute lesion were ruled out 2,3 .

More effective treatment can be obtained when those conditions are recognized ${ }^{3}$.

Opioid sparing or changing the opioid represents strategies adopted to prevent or treat $\mathrm{OIH}$, although convincing evidence for those conducts does not exist ${ }^{3}$. The concomitant use of low doses of opioid antagonists or the use of cholecystokinin or NMDA receptor antagonists are other strategies that could be used ${ }^{1,3}$.

The concomitant use of other analgesics, besides nonpharmacologic treatment, is the strategy used more often to avoid tolerance and opioid-induced hyperalgesia ${ }^{3,6}$.

In general, the reduction of the analgesic effect of the opioid during treatment is considered tolerance to the opioid, which leads to an increase in the dose. On the other hand, OIH can be aggravated by the increase in the dose of the opioid 1,6 . Opioid-induced hyperalgesia should be treated with a reduction in dose, changing of the opioid, or with the association of other analgesics ${ }^{3}$.

However, the mixture of tolerance and hyperalgesia could be produced by exposure to large doses of opioids ${ }^{4}$.

\section{CONCLUSION}

Opioid-induced hyperalgesia is very complex, involving a series of mechanisms that could contribute for patient discomfort, bringing harmful consequences when they are not diagnosed. 
02. Chu LF, Angst MS, Clark D - Opioid-induced hyperalgesia in humans: molecular mechanisms and clinical considerations. Clin J Pain, 2008:24:479-496.

03. DuPen A, Shen D, Ersek M - Mechanisms of opioid-induced tolerance and hyperalgesia. Pain Mange Nurs, 2007;8:113-121.

04. Guignard B, Bossard AE, Coste C et al. - Acute opioid tolerance: intraoperative remifentanil increases postoperative pain and morphine requirement. Anesthesiology, 2000;93:409-417.

05. Reznikov I, Pud D, Eisenberg E - Oral opioid administration and hyperalgesia inpatients with cancer or chronic nonmalignant pain. $\mathrm{Br} \mathrm{J}$ Clin Pharmacol, 2005;60:311-318.

06. Mao J - Opioid-induced abnormal pain sensitivity: implications in clinical opioid therapy. Pain, 2002;100:213-217.

07. Vanderah TW, Ossipov MH, Lai J et al. - Mechanisms of opioid-induced pain and antinociceptive tolerance: descending facilitation and spinal dynorphin. Pain, 2001;92:5-9.

08. Schmidt S, Bethge C, Förster M et al. - Enhanced postoperative sensitivity to painful pressure stimulation after intraoperative high dose remifentanil in patients without significant surgical site pain. Clin J Pain, 2007;23:605-611.

09. Joly V, Richebe P, Guignard B et al. - Remifentanil-induced postoperative hyperalgesia and its prevention with small-dose ketamine. Anesthesiology, 2005;103:147-155.

10. Célèrier $E$, Rivat $C$, Jun $Y$ et al. - Long-lasting hyperalgesia induced by fentanyl in

11. Collett BJ - Opioid tolerance: the clinical perspective. $\mathrm{Br} \mathrm{J}$ Anaesth, 1998;81:58-68.

12. Bruera $\mathrm{E}$, MacMillan $\mathrm{K}$, Hanson $\mathrm{J}$ et al. - The Edmonton staging system for cancer pain: preliminary report. Pain, 1989;37:203-209.

13. Jage $\mathrm{J}$ - Opiod tolerance and dependence: do they matter? Eur $\mathrm{J}$ Pain, 2005;9:157-162.

14. Simonnet G, Rivat C - Opioid-induced hyperalgesia: abnormal or normal pain? Neuroreport, 2003;14:1-7.

15. Ossipov MH, Lai J, King T et al. - Underlying mechanisms of pronociceptive consequences of prolonged morphine exposure. Biopolymers, 2005;80:319-324.

16. Gebhart GF - Descending modulation of pain. Neurosci Biobehav Rev, 2004; 27:729-737.

17. Liang D, Shi X, Qiao Y, et al. - Chronic morphine administration enhances nociceptive sensitivity and local cytokine production after incision. Mol Pain, 2008;4:7.

18. Mogil JS, Wilson SG, Chesler EJ et al. - The melanocortin-1 receptor gene mediates female-specific mechanisms of analgesia in mice and humans. Proc Natl Acad Sci USA, 2003;100:4867-4872.

19. Hood D, Curry R, Eisenach, JC - Intravenous remifentanil produces withdrawal hyperalgesia in volunteers with capsaicin-Induced hiperalgesia. Anesth Analg, 2003;97:810-815.

20. Cortinez LI, Brandes V, Munoz HR et al. - No clinical evidence of acute opioid tolerance after remifentanil-based anaesthesia. $\mathrm{Br} \mathrm{J}$ Anaesth, 2001;87:866-869.

21. Koppert W, Schmelz M - The impact of opioid-induced hyperalgesia for postoperative pain. Best Pract Res Clin Anaesthesiol, 2007;21:65-83.

22. Guntz E, Talla G, Roman A et al. - Opioid-induced hiperalgesia. Eu J Anaesthesiol, 2007;24:205-207.

23. Davis MP, Shaiova LA, Angst MS - When opioids cause pain. J Clin Oncol, 2007;25:4497-4498.

24. Doverty M, White JM, Somogyi A et al. - Hyperalgesic responses in methadone maintenance patients. Pain, 2001;90:91-96.

25. Yaksh TL, Harty GJ - Pharmacology of the allodynia in rats evoked by high dose intrathecal morphine. J Pharmacol Exp Ther, 1988;244:501507.

26. Kissin I, Brown PT, Bradley EL - Magnitude of acute tolerance to opioids is not related to their potency. Anesthesiology,1991;75:813-816.

\section{REFERÊNCIAS / REFERENCES}

01. Angst MS, Clark JD - Opioid-induced hyperalgesia: a quantitative systematic review. Anesthesiology, 2006;104:570-587. 
29. Vinik HR, Kissin I - Rapid development of tolerance to analgesia during remifentanil infusion in humans. Anesth Analg, 1998;86:13071311.

30. Koppert W, Angst M, Alsheimer M et al. - Naloxone provokes similar pain facilitation as observed after short-term infusion of remifentail in humans. Pain, 2003;106:91-99.

31. Rivat C, Laulin JP, Corcuff JB et al. - Fentanyl enhancement of carrageenan-induced long-lasting hyperalgesia in rats: prevention by the $\mathrm{N}$-methyl-D-aspartate receptor antagonist ketamine. Anesthesiology, 2002;96:381-391.

32. Ali NM - Hyperalgesic response in a patient receiving high concentrations of spinal morphine. Anesthesiology,1986;65:449-450.

33. Mao J, Price DD, Mayer DJ - Mechanisms of hyperalgesia and morphine tolerance: a current view of their possible interactions. Pain, 1995;62:259-274.

34. Singler B, Tröster A, Manering $\mathrm{N}$ et al. - Modulation of remifentanil-induced postinfusion hyperalgesia by propofol. Anesth Analg, 2007;104:1397-1403.

35. DeKock MF, Lavand'homme PM - The clinical role of NMDA receptor antagonist for the treatment of postoperative pain. Best Pract Res Clin Anaesthesiol, 2007;21:85-98.

36. Guignard B, Coste $\mathrm{C}$, Costes $\mathrm{H}$ et al. - Supplementing desfluraneremifentanil anesthesia with small-dose ketamine reduces perioperative opioid analgesic requirements. Anesth Analg, 2002;95:103-108.

37. Engelhardt T, Zaarour C, Naser B et al. - Intra-operative low-dose ketamine does not prevent a remifentanil-induced increase in morphine requirement after pediatric scoliosis surgery. Anesth Analg, 2008;107:1170-1175.

38. Grande LA, O'Donnell BR, Fitzgibbon DR et al. - Ultra-low dose ketamine and memantine treatment for pain in an opioid-tolerant oncology patient. Anesth Analg, 2008;107:1380-1383.
39. Troster A, Sittl R, Singler B et al. - Modulation of remifentanil-induced analgesia and postinfusion hyperalgesia by parecoxib in humans. Anesthesiology, 2006;105:1016-1023.

40. Koppert W, Sittl R, Scheuber K et al. - Differential modulation of remifentanil-induced analgesia and postinfusion hyperalgesia by Sketamine and clonidine in humans. Anesthesiology, 2003;99:152-159.

Resumen: Leal PC, Clivatti J, Garcia JBS, Sakata RK - Hiperalgesia Inducida por Opioides (HIO).

Justificativa y objetivos: Los opioides son medicamentos a menudo usados para el control del dolor y que sin embargo pueden causar hiperalgesia. La circunstancia por la cual ese fenómeno puede ocurrir no está totalmente aclarada. El objetivo de esta revisión es describir los mecanismos, los factores que están involucrados y la modulación por medicamentos.

Contenido: Fueron descritos los factores involucrados en el desarrollo de la hiperalgia inducida por opioides (HIO), como la duración en el uso, la dosis y el tipo de opioide. Los mecanismos incluyen los sistemas glutamatérgico y los receptores N-metil-D-aspartato (NMDA), activación de ciclo-oxigenasa (COX) espinal, aminoácidos excitatorios, dinorfina, citocinas y quimocinas; prostaglandinas y facilitación descendiente. La modulación de la hiperalgesia se puede lograr con los antagonistas de receptores NMDA, los agonistas adrenérgicos-alfa2 y con los inhibidores de (COX).

Conclusiones: El tema es bastante complejo, e involucra una serie de mecanismos fisiopatológicos que pueden contribuir para la $\mathrm{HIO}$ y la incomodidad del paciente, con consecuencias dañinas para la salud. 